\title{
Teachers' Job Satisfaction and Work Performance
}

\author{
Genelyn R. Baluyos' ${ }^{1}$, Helen L. Rivera ${ }^{2}$, Esther L. Baluyos ${ }^{1}$ \\ ${ }^{1}$ Misamis University, Ozamiz City, Philippines \\ ${ }^{2}$ DepEd, Division of Misamis Occidental, Philippines \\ Email: genelynbaluyos@gmail.com, helenrivera70@gmail.com, estherlaborbaluyos@gmail.com
}

How to cite this paper: Baluyos, G.R., Rivera, H.L. and Baluyos, E.L. (2019) Teachers' Job Satisfaction and Work Performance. Open Journal of Social Sciences, 7, 206-221.

https://doi.org/10.4236/jss.2019.78015

Received: June 27, 2019

Accepted: August 17, 2019

Published: August 20, 2019

Copyright () 2019 by author(s) and Scientific Research Publishing Inc. This work is licensed under the Creative Commons Attribution International License (CC BY 4.0).

http://creativecommons.org/licenses/by/4.0/

(c) (i) Open Access

\begin{abstract}
Job satisfaction is a requirement for the work performance of the teacher. This study determined the relationship of teachers' job satisfaction and their work performance in the Division of Misamis Occidental during the school year 2018-2019. One hundred and four (104) school heads and three hundred and thirteen (313) teachers responded to the study. The researcher used the descriptive-correlational research design; and the Teacher Job Satisfaction Survey Questionnaire (TJSQ) and Individual Performance Commitment Review Form (IPCRF) as instruments. Mean, standard deviation, and Multiple Regression Analysis were the statistical tools used. Findings revealed that the teachers were highly satisfied with their job, and their work performance was very satisfactory. The satisfaction of teachers on school heads' supervision and job security inversely affect the teachers' work performance. Schools have to be provided with the faculty lounge so teachers can talk freely on their well-being. Human Resource Department officers have to include in their teacher retention strategies the teachers' welfare packages. Future researchers have to look into other factors that might predict the teachers' work performance.
\end{abstract}

\section{Keywords}

Job Satisfaction, Performance, Security, Supervision, Welfare, Well-Being

\section{Introduction}

Job satisfaction plays an essential role in the overall commitment and productivity of the school organization. The teachers' job satisfaction significantly influenced their commitment to the organization. Teachers who are satisfied with the job are also committed to work in the organization. The more the employers are 
satisfied in the job; the better is their participation and commitment to the organization [1]. The happy or satisfied feeling of the teachers towards the organization affects the overall process in carrying their job, thus, contributes to the school success as a whole [2].

Job satisfaction affects students' performance; and educational improvement is not possible without improving these two factors. It leads towards school improvement, quality education, and student satisfaction, which is the ultimate goal of any organization. Besides, this variable significantly affects leadership behavior, work performance, and styles [3]. It is critical in one's work. Adaptability, job motivation, and job success may influence each other. Satisfaction, health security creditability, and meeting basic requirements can be achieved when performance is better [4].

Job satisfaction had a positive effect on life satisfaction [5]. Motivation had a significant positive correlation with a willingness to stay with a job, while extrinsic motivation, integrative motivation, and demotivation had a significant negative relationship with a desire to stay with the job. The results of synchronous multi-variate regression indicated that six components of self-determined job motivations had multiple significant correlations with job satisfaction and willingness to remain with job among female elementary school teachers [6].

Male teachers are less satisfied than female teachers [7]. However, female teachers appeared to experience more personal accomplishment and job satisfaction than male teachers. Similarly, in Delhi, job satisfaction significantly differed between male and female but no difference between institutions [8]. Teachers who graduated from arts and sciences were found to have a higher level of personal accomplishment, and job satisfaction than teachers who graduated from education [9].

In Southern Tulare County, California, the teachers at each school have moderately high to high levels of job satisfaction. Teacher job satisfaction has a direct impact on teacher retention, instructional performance, positive school climate, and increased student achievement [10]. Another study was conducted from six government secondary schools in the district of Penampang, Sabah, Malaysia. The teachers found to be reasonably satisfied with their job, with the responsibility factor as the most significant contributor to job satisfaction. Based on the years of service in their current school, a statically significant difference in the level of job satisfaction among the teachers was noted. Secondary schools in Sabah have a positive and open climate, with the professional teachers' behavior factor as the most significant contributor. The results indicate the necessity to provide a positive organizational environment [11].

Turkish elementary science teachers experience a high level of personal accomplishment and job satisfaction. As class size and weekly course hour increase, elementary science teachers tend to experience more emotional exhaustion but less job satisfaction. Professional community, collaboration, and teacher control are predictive of satisfaction, and these also have interactive influences. 
The association between teacher collaboration and job satisfaction, as well as that between control over classroom policy and job satisfaction, is most pronounced in schools with weaker professional communities [12].

Job satisfaction is a significant influence on whether teachers are willing to encourage others to join the profession. Job demands were the most significant predictor in the model, while extrinsic motivations were the only negative predictor in each model [13]. Teachers were less willing to encourage their family members, including their children, while being more willing to promote either students or student teachers, to join the profession. Spirituality and general job satisfaction were moderately and positively correlated. Spirituality is related to job satisfaction for selected teachers. However, it is not related to the general job satisfaction scale [14]. Job satisfaction is strongly associated with psychological aspects. Those who are satisfied with the job are also emotionally adaptive and satisfactorily enjoyed [4]. Teachers from six universities in Shenyang, China had a moderate level of job satisfaction. Demographic and working characteristics were associated factors for job satisfaction. Perceived organizational support showed the most active association with job satisfaction [15].

The grade level taught revealed a moderate difference in job satisfaction perceptions. The most satisfied teachers are teaching from high school, while the least satisfied are coming from middle school level. As the years of teaching experience increases, the level of job satisfaction decreases [16].

The innovative role of a teacher as facilitator in the classroom is different from the part of the controller and organizer of all activities that $\mathrm{s} / \mathrm{he}$ plays in a traditional class. Facilitation involves lowering the teacher's authority by endowing more powers to learners for more initiative and responsibility. In the conventional teacher-fronted classroom, the learner is always under the firm control of the teacher who decides what to do, while in a learner-centered classroom, the teacher instead, a facilitator is expected to let go of some of his or her power. Learner-centeredness allows the learner higher authority to do most of the activities of the lesson [17].

The quality of the performance of the licensed teachers in planning the lesson was low. The license or certificate that they have does not guarantee an increase in the teachers' teaching performance, especially in lesson planning [18]. In Central Java province, the variables competence, motivation, and innovativeness had a positive and significant impact on performance variables. The most dominant factor affecting the performance and innovation of mathematics teachers is competence [19]. The teachers' performance improved through attitude modification, work motivation, and favorable organizational culture in schools [20].

Teacher's satisfaction is crucial for better teaching performance. Results showed that excellent teachers had low satisfaction in terms of "personal growth" and "supervision" [21]. Structural relationships among innovative school climate, knowledge sharing, work engagement, and knowledge creation activities among high school teachers in Korea were examined. The results indicated that a creative school climate positively influences teachers' knowledge sharing and work 
engagement; and affects the outcome variable, teachers' knowledge creation practices [22].

The strong and significant relationship among the work-life balance and work-family conflict, family-work conflict, work environment, and feelings about work was found. Feeling about work is the most influencing factor of work-life balance. Attitudes about work, conducive work environment, reduced work-family conflict, and reduced family-work conflict resulted in stable work-life balance and ultimately on job satisfaction for the employees [23]. Teachers generally having a negative attitude towards pay-for-performance were seen. Teachers felt that morale and teacher collaboration would be affected negatively as well as increasing stress levels. Having pay-for-performance based on individual student achievement or standardized tests was also seen as a negative result [24].

In public primary schools of Calabar, a study revealed that head teachers' decision-making strategy and leadership style have a significant influence on teachers' task performance in the sampled schools. Also, head teachers' communication skills significantly relate to teachers' task performance in the area. Proper managerial behavior to boost teachers' morale towards high task performance has to be adopted [25]. [26] found that differences and relationships exist between teachers and principals in terms of how much they believe specific leadership practices influence school performance. Principals tend to see challenging teachers' past beliefs about their work and assumptions about students as a more influential leadership practice concerning school performance. While both teachers and principals feel that providing individual support is essential, only principals believe that building vision is necessary.

In the Philippines, a study in the Lyceum of the Philippines University, Batangas City, the job satisfaction of the teaching and non-teaching staff was conducted. Results revealed that LPU-Batangas had a high level of job satisfaction in terms of maintenance/hygiene factors and satisfiers/motivation factors. There was a significant relationship between hygiene and motivation factors based on the level of job satisfaction of teaching and non-teaching staff [27].

Another study in the Philippines revealed that teachers who are satisfied with their teaching assignments or jobs were predominantly female, equipped with a Masters' degree, and with an average teaching experience of nine years. The employees expressed strong agreement with university practices such as setting clear goals, encouraging innovation for organizational effectiveness and continuous improvement through a quality management system [28]. However, educational attainment and experience are the most important factors for predicting success as an administrator in higher education [29]. Job enrichment has to include not only the knowledge, experience, and skills of administrators but the context and working conditions of employees.

High-performance work systems, directly and indirectly influence teachers' in-role performance and extra-role behavior through the mediation of the quality of working life. Quality of working life is an essential conduit of the relation- 
ships between high-performance work systems and employee's work behaviors [30]. Structural relationships among learning-organization culture, self-efficacy, work engagement, and job performance in Korean workforce institutions were conducted. Teachers' self-efficacy positively affected their work engagement and job performance, and the relationship between work engagement and job performance was statistically significant. Also identified were the mediating roles of self-efficacy and work engagement on the relationships between the learning-organization culture of workforce-education schools and the teachers' job performance [31].

There was a difference in the teachers' teaching performance between those teachers teaching in different schools and those teachers teaching in the same school. The basis for promotion and professional development was only the students' tests scores, without considering the increased teaching loads that they have. Teachers' autonomy and performance have to be also considered to improve the quality of teaching [32]. However, independence and work-life balance were related significantly to the teachers' job performance, but workload did not contribute to the job performance among school teachers [33].

Many professions are considered delicate and challenging. Some teachers were afraid that they did not have the skills necessary for teaching children [34]. Creating a healthy learning environment is of paramount concern to most teachers, and appropriate development of that environment is a challenge faced during student-teaching [35]. Thus, managing a classroom is a must skill introduced in as early as practice teaching.

A study that assessed the relationship between teacher retention and job security in private secondary schools in Ogun state, Nigeria revealed that retention strategies and job security were related significantly in private secondary schools [36]. The empathetic concern of the selected principals had contributed positively to the work performance of teachers. Rewards and punishment did not impact to the improved performance of teachers. Teachers who worked in schools that implement Positive Behavioral Interventions and Supports (PBIS) had better performance rating in posting, teaching, reviewing, monitoring, and reinforcing expectations than those who did not. Additionally, teachers with exclusive education license were a better performer in maximizing structure, using different strategies and techniques in classroom management than those who were not [37].

As educators, it is necessary to look into the factors related to teachers' job satisfaction that may affect their work performance. Hence, the researchers would like to determine the relationship between the teachers' job satisfaction and their work performance.

\subsection{Theoretical Framework}

This study anchored on Herzberg's Motivator-Hygiene Theory. Herzberg's Motivator-Hygiene Theory is known as Herzberg's Two Factor Theory. It states that 
there are two opposite ends-job satisfaction and dissatisfaction of the continuum. An employee needs to meet the motivating factors like pay and benefits, recognition, and achievement so that he will be satisfied with his work. However, the absence of "hygiene" factors like working conditions, company, policies, and structure, job security, interaction with colleagues and quality of management, the employee will be dissatisfied with his job. If an employer wants to motivate his team to perform better in the company, then he needs to focus on factors that lead to satisfaction like achievement, recognition, and responsibility [38].

\subsection{Objectives of the Study}

This study determined the relationship on the teachers' level of job satisfaction and their work performance in the Division of Misamis Occidental. Specifically, the study answered the following objectives:

1) Determine the teachers' job satisfaction as to supervision, colleagues, working conditions, pay, responsibility, work itself, advancement, security, and recognition;

2) Determine teachers' work performance as to teaching-learning process, pupils' outcomes, community involvement, professional growth, and other accomplishments; and

3) Explore the significant relationship between the teachers' job satisfaction and work performance.

\section{Methods}

\subsection{Research Design}

This study used descriptive-correlational design. The research design is used to explain phenomena, attitudes, opinions, and behaviors or other defined variables by collecting numerical data which are analyzed using statistically based methods [39]. The descriptive-correlational design was appropriate for this study, which assessed the teachers' job satisfaction and work performance.

\subsection{Research Setting}

The study was conducted in the first and second Congressional Districts of the Division of Misamis Occidental. The first congressional district comprised of Jimenez, Panaon, Aloran, Lopez Jaena, Plaridel North, and Plaridel South. The second congressional district included Sinacaban, Tudela, Clarin North, Clarin South, Bonifacio East, Bonifacio West, and Don Victoriano.

\subsection{Respondents of the Study}

The respondents of the study were one hundred four (104) school heads and three hundred thirteen (313) Elementary school teachers of the Division of Misamis Occidental chosen through stratified random sampling. Below is a list of respondents. 


$\begin{array}{lll}\text { District } & \text { School Heads } & \text { Teachers } \\ \text { First Congressional District } & 51 & 173 \\ \text { Second Congressional District } & 53 & 140 \\ \text { Total } & 104 & 313\end{array}$

\subsection{Research Instruments}

The following research instruments were used in the gathering of data and information in the study.

1) Teacher Job Satisfaction Survey Questionnaire (TJSQ). It is a 62-item questionnaire with nine constructs, adopted and modified from (Lester, 1987), designed to measure the level of job satisfaction of teachers. Responses were solicited using a five-point scale ranging from 5 (always) to never (1). Five experts validated the tool for them to decide whether to retain, revise, or reject the indicators. After which, the corrections of the experts were incorporated into the final draft. It was then pilot-tested to teachers who were not included as the respondents of the study. The Cronbach's Alpha coefficient was 0.96 . Hence it was valid and reliable.

The following continuum was used to determine the teacher's level of job satisfaction:

$\begin{array}{lll}\text { Responses } & \text { Continuum } & \text { Interpretation } \\ \text { 5-Always (A) } & 4.20-5.0 & \text { Very Highly Satisfied (VHS) } \\ \text { 4-Often (A) } & 3.40-4.19 & \text { Highly Satisfied (HS) } \\ \text { 3-Sometimes (S) } & 2.60-3.39 & \text { Moderately Satisfied (MS) } \\ \text { 2-Rarely (R) } & 1.80-2.61 & \text { Least Satisfied (LS) } \\ \text { 1-Never (N) } & 1.0-1.81 & \text { Not Satisfied (NS) }\end{array}$

2) Teachers' Work Performance Instrument. Documentary analysis was observed in the research. The study utilized the performance of teachers during the School Year 2018-2019 as rated by their school heads. In determining the work performance of the teachers, the following continuum was used.

$\begin{array}{lll}\text { Responses } & \text { Continuum } & \text { Interpretation } \\ \text { 5-Always (A) } & 4.20-5.0 & \text { Outstanding (O) } \\ \text { 4-Often (O) } & 3.40-4.19 & \text { Very Satisfactory (VS) } \\ \text { 3-Sometimes (S) } & 2.60-3.39 & \text { Satisfactory (S) } \\ \text { 2-Rarely (R) } & 1.80-2.59 & \text { Fair (F) } \\ \text { 1-Never (N) } & 1.0-1.79 & \text { Poor (P) }\end{array}$

\subsection{Data Collection}

The researchers secured a certification and letter of request from the Graduate School of Misamis University. Then, approval of the Schools Division Superintendent in the Division of Misamis Occidental was sought for the conduct of the study. Similar permission was obtained from the District Supervisor of the second Congressional District of the division of Misamis Occidental and the principals of the elementary schools. The researcher personally did the actual data gathering. The data gathered were tallied, organized, treated statistically, 
interpreted, and analyzed.

\subsection{Ethical Considerations}

The following were the ethical considerations observed by the researcher to ensure the integrity of the research process: 1 ) informed consent of the participants and respondents had been obtained before involving them in the study; 2) members of the sample group had not been subjected to coercion in any way; 3 ) privacy of the research respondents had been ensured, so that no personal data were collected from the respondents; 4) research respondents had been debriefed about the aims and objectives of the study before the primary data collection process ; 5) works that do not belong to the author of this paper had been acknowledged using APA referencing system in an appropriate format; 6) analysis of data was filtered through the researcher's particular theoretical position and biases; 7) in case of harm inflicted by the researcher, the research was held responsible, and 8) top priority and confidentiality was maintained at all times during the conduct of the study.

\subsection{Data Analysis}

With the use of Minitab software, the following statistical tools were used in interpreting the data of this study:

Mean and Standard Deviation. These were used in determining the teachers' level of job satisfaction and work performance.

Multiple Regression Analysis was used to explore the relationship between the teachers' level of job satisfaction and work performance.

\section{Results and Discussion}

\subsection{Teachers' Level of Job Satisfaction}

Data in Table 1 revealed that in general, the teachers' level of job satisfaction was very high $(M=4.56 ; S D=0.65)$. They were very highly satisfied in their job in all areas as evident in teachers' highest rating on responsibility $(\mathrm{M}=4.80$; $\mathrm{SD}=$ $0.35)$ and even in lowest rating in pay $(\mathrm{M}=4.24 ; \mathrm{SD}=0.77)$. Two areas, responsibility $(\mathrm{M}=4.80, \mathrm{SD}=0.35)$ and advancement $(\mathrm{M}=4.71 ; \mathrm{SD}=0.94)$ received the first two highest ratings. However, pay factor $(\mathrm{M}=4.24$; $\mathrm{SD}=0.77)$ and recognition factor $(M=439, S D=0.69)$ were rated lowest by the teachers.

This means that due to the support and supervision of the school heads, the teachers get satisfied with their job. Moreover, they help their colleagues in their teaching career, also attributed to pleasant working conditions. The teachers also see their compensation adequate to satisfy all their usual needs. It can also be noted that the teachers were delighted with their uniform rate. At every rank they earn, they get the corresponding rise in pay by their performance and other factors. They feel responsible for their actions and the delivery of lessons for student learning. They view teaching as a social work which provides an opportunity to use a variety of skills. They feel secure in the job, and they are 
Table 1. Teachers' job satisfaction.

\begin{tabular}{lll}
\hline \multicolumn{1}{c}{ Constructs } & $\mathrm{M}$ & $\mathrm{SD}$ \\
\hline 1) Supervision & 4.47 & 0.65 \\
2) Colleagues & 4.65 & 1.03 \\
3) Working conditions & 4.50 & 0.55 \\
4) Pay & 4.24 & 0.77 \\
5) Responsibility & 4.80 & 0.35 \\
6) Work Itself & 4.68 & 0.39 \\
7) Advancement & 4.71 & 0.94 \\
8) Security & 4.56 & 0.55 \\
9) Recognition & 4.39 & 0.61 \\
Overall Job Satisfaction & 4.56 & 0.65 \\
\hline
\end{tabular}

Note: Scale: 4.20 - 5.0 (Very Highly Satisfied); 3.20 - 4.19 (Highly satisfied); 2.60 - 3.19 (Moderately Satisfied); 1.80 - 2.60 (Less Satisfied); 1.0 - 1.79 (Least Satisfied).

recognized in the teaching career through rewards and other forms. However, the teachers rated compensation and recognition the lowest among all areas, though they are still very highly satisfied. Hence, the organization has to look into how to improve these areas.

Employees who are satisfied in the job are adaptive emotionally and enjoyed satisfactorily [4]. Job satisfaction is essential to the success of the situation. It leads to a higher efficiency rating and increases the level of motivation. Adaptability, job motivation, and job success may influence the creation of job satisfaction [4]. The satisfaction level of excellent teachers which was low in terms of personal growth and supervision [5] contradicts to the finding of this study since all factors are rated very highly satisfied and highly satisfied.

Teachers are essential factors in the teaching-learning process. It is vital that teachers are satisfied with the working conditions that they have for them to perform well and therefore, deliver quality education to students. They have to be given attention by their immediate heads or supervisors. These can be done through the visibility of the principal/school heads or supervisors. It is also essential that the colleagues are supporting each other. Unity among the members will give a significant impact to the organization as they will embody the sense of responsibility of all of their actions. School heads have to ensure that due recognition for teachers with exemplary performance in the school is done to boost their self-esteem, thus provide them with the feeling of security of their work. Advancement in the profession has to be also ensured to help the teachers increase their self-efficacy and eventually improve the quality of teaching.

\subsection{Teachers' Work Performance}

The teachers' work performance in general $($ Table 2$)$ is very satisfactory $(M=$ 
Table 2. Teachers' work performance.

\begin{tabular}{lcc}
\hline Constructs & $\mathrm{M}$ & $\mathrm{SD}$ \\
\hline 1) Teaching learning process & 4.03 & 0.52 \\
2) Pupils' outcomes & 4.23 & 0.30 \\
3) Community involvement & 4.17 & 0.75 \\
4) Professional growth and development & 4.09 & 0.59 \\
Overall Performance & 4.13 & 0.54 \\
\hline
\end{tabular}

Note: Scale: 4.20 - 5.0 (Outstanding); 3.20 - 4.19 (Very Satisfactory); 2.60 - 3.19 (Satisfactory); 1.80 - 2.59 (Fair); 1.0 - 1.79 (Poor).

4.13; $\mathrm{SD}=0.54)$. Only the area on pupils' outcomes where the teachers received an outstanding rating $(\mathrm{M}=4.23 ; \mathrm{SD}=0.30)$. The teachers' performance on teaching-learning process $(\mathrm{M}=4.03 ; \mathrm{SD}=0.52)$, community involvement $(\mathrm{M}=$ $4.17 ; \mathrm{SD}=0.75)$, and professional growth and development $(\mathrm{M}=4.09 ; \mathrm{SD}=$ $0.59)$ received a very satisfactory rating from their school heads and supervisors.

The overall performance of teachers indicated that the teachers were able to carry their job very satisfactorily in the teaching-learning process, in initiating activities that promote parents and community members' participation, and in updating themselves through attending seminars, workshops, and conferences. However, teachers were excellent or outstanding in monitoring and evaluating pupils' progress and providing remedial instructions for slow learners beyond class hours.

Teacher's performance could be improved through attitude modification, work motivation, and favorable organizational culture in schools [20]. Some teachers were afraid that they did not have skills necessary for teaching children [34] but for some, creating a healthy learning environment is of paramount concern and challenges faced during teaching [35].

The very satisfactory performance of teachers contradicts to the study of [18] which stated that teachers' performance in planning the lesson was low. The most dominant factor affecting the performance and innovation of is competence [19]. The focus of teaching and on teachers' autonomy is needed to achieve the goal of improving the quality of education [32]. Independence and work-life balance had a significant impact on teachers' job performance [33]. Promoting perceptions of meaningful work might contribute to higher work engagement, better self-ratings of performance, and retention of teachers [40].

To enhance the performance of teachers in the teaching-learning process, the school has to invest and allocate an adequate amount for the professional development program of all teachers. They should not be confined only in the four walls of the classroom, but they have to be allowed to keep abreast of all the updates in teaching. They are duty bound to work with other people in the community aside from doing daily routines in education. Thus, training and workshops whether in local, national or international that promote the better performance of teachers in teaching and in fostering activities that attract the people in 
the community to participate for the betterment of the school are necessary.

\subsection{Significant Relationship between the Teachers' Job}

\section{Satisfaction and Work Performance}

Regression analysis was used to explore the predictors of the teachers' work performance which resulted to p-values lesser than 0.01 alpha level (Table 3). Data revealed that among the nine factors in teachers' job satisfaction, only two factors-supervision $(\beta=-0.09 ; \mathrm{t}=2.93, \mathrm{p}=0.004)$ and security $(\beta=0.10 ; \mathrm{t}=2.85$, $\mathrm{p}=0.005)$ affect their work performance. Other factors like colleagues,

working conditions, pay, responsibility, work itself, advancement, and recognition do not affect the teachers' work performance. These factors are not the predictors of work performance of teachers.

The regression equation (Overall Work Performance $=4.056-0.09$ Supervision +0.10 Security) indicates that 9 percent of teacher' satisfaction of supervision factor affects their work performance and 10 percent of the teachers' satisfaction on security affects their work performance. It implies that when the teachers' level of satisfaction in terms of supervision increases by one unit, their work performance decreases by 9 percent. The more their school heads supervised closely, the less they perform on their job. They do not want to be tightly controlled by their school heads. However, when the level of satisfaction of teachers increases by one unit, their work performance also increases by 10 percent. The more the teachers feel secure in their job and their future, the better is their work performance.

The data with $\left(\mathrm{r}^{2}=3.98 \%\right)$ shows that only $3.98 \%$ of the teachers' work performance is attributed to their job satisfaction in the area of supervision and security; while the remaining $96.02 \%$ is attributed to other factors which are not included in the study. Thus, future researchers have to look into these factors that might predict the teachers' work performance.

The finding of this study contradicts to the study of [36], which showed that the use of an empathetic concern by kindergarten principals had a positive effect

Table 3. Test of significant relationship between the teachers' job satisfaction and work performance.

\begin{tabular}{|c|c|c|c|c|c|}
\hline Source & Df & Sum of Squares & Mean Square & F-value & $\mathrm{p}$-value \\
\hline Regression & 2 & 1.43 & 0.72 & $6.53^{* *}$ & 0.002 \\
\hline Total & 317 & 35.96 & & & \\
\hline Predictors & & Coef $(\beta)$ & SE Coef & T-Value & P-Value \\
\hline (Constant) & & 4.06 & 0.18 & 22.59 & ${ }^{* *} 0.000$ \\
\hline 1) Supervision & & -0.09 & 0.03 & 2.93 & ${ }^{* *} 0.004$ \\
\hline 2) Security & & 0.10 & 0.36 & 2.85 & ${ }^{* *} 0.005$ \\
\hline
\end{tabular}

Dependent Variable: Teachers' Work Performance

Overall Work Performance $=4.056+0.0873$ Supervision +0.10 Security; $\mathrm{R}^{2}=3.98 \%$

Note: ${ }^{* *}$ means $\mathrm{p}<0.01$ (Highly Significant) at 0.01 level. 
on teachers' work performance. The supervision practices of principals are indeed helpful in attaining better performance of teachers and their overall growth [41]. However, a study of [42] supported this finding and revealed a significant relationship between job security and their longevity of stay as a professional teacher in private secondary schools in Osun state. The study also showed a significant correlation between teachers' job security and their teaching work performance in schools.

The very high level of teachers' satisfaction towards their school heads' supervision does not contribute to teachers' work performance; while the very high level of satisfaction on job security matters on their performance. Hence, school heads have to lessen their supervision to their teachers. This is to give their teachers the autonomy and to exercise their self-efficacy that teachers can do tasks by themselves without constant follow-up from their school heads. Teachers also have to be assured by the school administrators that they are safe and secured in their job and their future. Instead of being a concern of the teachers' performance, school heads' attention has to be focused on teachers' job security. Faculty lounge has to be provided in schools so that school heads and teachers can talk and plan freely of their welfare in the future.

\section{Conclusions and Recommendations}

Teachers' satisfaction is crucial to their teaching performance. The teachers' very high level of job satisfaction on school heads' supervision and job security is contributory factor to their work performance. The teachers' work performance is inversely affected by the school heads' guidance and directly affected by the teachers' job security.

The study recommends that school heads minimize their supervision on their teachers' teaching performance but maximize their concern over the welfare of their teachers. School Human Resource Department officers have to include in their teacher retention strategies the prompt payment of salary, teachers' welfare packages, and the provision of essential amenities to ensure job security in public elementary schools.

\section{Conflicts of Interest}

The authors declare no conflicts of interest regarding the publication of this paper.

\section{References}

[1] Shila, J.M. and Sevilla, A.V. (2015) The Influence of Teachers' Job Satisfaction on Their Organizational Commitment: An Indian Context. International Journal of Education and Management Studies, 5, 53-57. https://search.proquest.com/docview/1680664175?accountid=149218

[2] Sadasa, K. (2013) The Influence of Organizational Culture, Leadership Behavior, and Job Satisfaction towards Teacher Job Performance. Indian Journal of Health and Wellbeing, 4, 1637-1642. 
https://search.proquest.com/docview/1614334457?accountid=149218

[3] Maqbool, S. (2017) Interrelationship between Collective Teacher Efficacy and Job Satisfaction of Teachers at Secondary Schools. NUML Journal of Critical Inquiry, 15, 180-196. https://search.proquest.com/docview/2011249258?accountid=149218

[4] Mirzaii, L.H., Riazi, Z., Vares, M. and Alamgard, S. (2014) The Relation between Working Life Quality and Coping with Stress Styles and Job Satisfaction in Exceptional Schools' Teachers. Arabian Journal of Business and Management Review (Oman Chapter), 4, 60-64. https://doi.org/10.12816/0016570 https://search.proquest.com/docview/1555353416?accountid=149218

[5] Bachtiar, D., Sudibjo, N. and Bernarto, I. (2018) The Effects of Transformational Leadership, Perceived Organizational Support on Job and Life Satisfaction of Preschool Teachers. International Information Institute (Tokyo) Information, 21, 1301 1320. https://search.proquest.com/docview/2064332137? accountid=149218

[6] Asgari, Z., Rad, F.M. and Chinaveh, M. (2017) The Predictive Power of Self-Determined Job Motivation Components in Explaining Job Satisfaction and Willingness to Stay with Job among Female Elementary School Teachers in Shiraz. Indian Journal of Health and Wellbeing, 8, 173-176. https://search.proquest.com/docview/1890811951?accountid=149218

[7] Nazim, F. and Mahmood, A. (2018) A Study of Relationship between Leadership Style and Job Satisfaction. Journal of Research in Social Sciences, 6, 165-181. https://search.proquest.com/docview/2006709466? accountid=149218

[8] Tahir, S. and Sajid, S.M. (2014) Job Satisfaction among College Teachers: A Comparative Analysis. IUP Journal of Organizational Behavior, 13, 33-50. https://search.proquest.com/docview/1511117666?accountid=149218

[9] Yerdelen, S., Sungur, S. and Klassen, R.M. (2016) Relationship between Turkish Elementary Science Teachers' Occupational Well-Being and Some Contextual and Demographic Characteristics: A Multivariate Analysis. Egitim Ve Bilim, 41, 147-161. https://search.proquest.com/docview/1904771941 ?accountid=149218 https://doi.org/10.15390/EB.2016.4257

[10] Stoll-Lollis, C. (2015) Exploring Principal Leadership Behaviors and Their Impact on Teacher Job Satisfaction in Southern Tulare County, California (Order No. 3739366). https://search.proquest.com/docview/1749706944? accountid=149218

[11] Ghavifekr, S. and Pillai, N.S. (2016) The Relationship between School's Organizational Climate and Teacher's Job Satisfaction: Malaysian Experience. Asia Pacific Education Review, 17, 87-106. https://doi.org/10.1007/s12564-015-9411-8

[12] Stearns, E., Banerjee, N., Moller, S. and Mickelson, R.A. (2015) Collective Pedagogical Teacher Culture and Teacher Satisfaction. Teachers College Record, 117, 17-18. https://search.proquest.com/docview/1695777475?accountid=149218

[13] England, E.S. (2016) The Relationship among Reasons Teachers Entered the Profession, Job Satisfaction, and Encouraging Future Teachers (Order No. 10106054). https://search.proquest.com/docview/1791142276? accountid=149218

[14] Forsythe, G.L. (2016) Spirituality and Job Satisfaction: A Correlational Study of Elementary School Teachers (Order No. 10239617). https://search.proquest.com/docview/1853947059?accountid=149218

[15] Pan, B., Shen, X., Liu, L., Yang, Y. and Wang, L. (2015) Factors Associated with Job Satisfaction among University Teachers in Northeastern Region of China: A Cross-Sectional Study. International Journal of Environmental Research and Public Health, 12, 12761-12775. https://doi.org/10.3390/ijerph121012761 https://search.proquest.com/docview/1733897180?accountid=149218 
[16] Churchwell, M.S. (2016) A Study of Factors That Influence Job Satisfaction of Teachers at a Southeast Christian School (Order No. 10587683). https://search.proquest.com/docview/1886443023? accountid=149218

[17] Gulnaz, F., Alfaqih, A.M. and Mashhour, N.A. (2015) Paradigm Shift: A Critical Appraisal of Traditional and Innovative Roles of an English Teacher in Saudi ELT Classrooms. Theory and Practice in Language Studies, 5, 934-946.

https://doi.org/10.17507/tpls.0505.07

[18] Salingkat, S. (2017) Evaluation of Certified Teachers' Performance at SMPN 6 Luwuk, Banggai Regency, Indonesia. International Journal of Education \& Literacy Studies, 5, 24-31. https://doi.org/10.7575/aiac.ijels.v.5n.4p.24

[19] Huda, S., Laju, I.K. and Suwiyadi, S. (2018) The Influence of Motivation Work and Competence on Performance of Mathematics Teachers with Innovation as Intervening Variable. International Information Institute (Tokyo) Information, 21, 539546. https://search.proquest.com/docview/2038674868? accountid=149218

[20] Sutriyantono, A.T. and Rubin, B. (2013) The Relationship between Teacher Professional Attitudes, Work Motivation, along with Organizational Culture towards Teacher Performance. Indian Journal of Positive Psychology, 4, 571-574. https://search.proquest.com/docview/1614019895?accountid=149218

[21] Amzat, I.H., Don, Y., Fauzee, S.O., Hussin, F. and Raman, A. (2017) Determining Motivators and Hygiene Factors among Excellent Teachers in Malaysia. The International Journal of Educational Management, 31, 78-97. https://doi.org/10.1108/IJEM-03-2015-0023 https://search.proquest.com/docview/1861056418?accountid=149218

[22] Song, J.H., Kim, W., Chai, D.S. and Bae, S.H. (2014) The Impact of an Innovative School Climate on Teachers' Knowledge Creation Activities in Korean Schools: The Mediating Role of Teachers' Knowledge Sharing and Work Engagement. KEDI Journal of Educational Policy, 11, 179-203. https://search.proquest.com/docview/1641932284?accountid=149218

[23] Pandu, A. (2017) Sources Accountable for Work Life Stability among Married IT Women Employees and School Teachers in Chennai. Journal of Organisation and Human Behavior, 6, 29-37. https://search.proquest.com/docview/2024131836?accountid=149218

[24] Russ, R.D. (2015) Teacher Attitudes Regarding Performance-Based Pay (Order No. 3707142). https://search.proquest.com/docview/1696057914? accountid=149218

[25] Mbon, U.F. (2017) Head Teachers' Managerial Behavior and Teachers' Task Performance in Public Primary Schools in Calabar-South Local Government Area, Cross River State, Nigeria. Global Journal of Educational Research, 16, 163-169. https://doi.org/10.4314/gjedr.v16i2.11

[26] Matson, B.D. (2018) A Study of Teachers' and Principals' Beliefs about Leadership Behaviors in Relation to School Performance (Order No. 10840434). https://search.proquest.com/docview/2089412269? accountid=149218

[27] Javier, E.R. and Deligero, J.C.L. (2014) Job Satisfaction of the Teaching and NonTeaching Staff of the Lyceum of the Philippines University-Batangas. International Journal of Information, Business and Management, 6, 1-10. https://search.proquest.com/docview/1552838173?accountid=149218

[28] Kalaw, J.F. (2014) Organizational Culture among Teaching Employees of Lyceum of the Philippines University-Batangas: Basis of Enhancement. International Journal of Information, Business and Management, 6, 52-66. https://search.proquest.com/docview/1552838284?accountid=149218 
[29] Adeyemo, K.S., Sehoole, C. and Cueno, C.G. (2015) The Use of the Job Enrichment Technique for Decision-Making in Higher Education: The Case of the Philippines. SA Journal of Human Resource Management, 13, a645. https://doi.org/10.4102/sajhrm.v13i1.645

[30] Shen, J., Benson, J. and Huang, B. (2014) High-Performance Work Systems and Teachers' Work Performance: The Mediating Role of Quality of Working Life. Human Resource Management, 53, 817. https://doi.org/10.1002/hrm.21614 https://search.proquest.com/docview/1566643818?accountid=149218

[31] Song, J.H., Bae, S.H., Park, S. and Kim, H.K. (2018) Influential Factors for Knowledge Creation Practices of CTE Teachers: Mutual Impact of Perceived School Support, Transformational Leadership, and Work Engagement. Asia Pacific Education Review, 14, 467-482. https://doi.org/10.1007/s12564-013-9283-8

[32] Wang, L., Lai, M. and Lo, L.N. (2014) Teacher Professionalism under the Recent Reform of Performance Pay in Mainland China. Prospects, 44, 429-443. https://doi.org/10.1007/s11125-014-9315-0

[33] Johari, J., Yean Tan, F. and Tjik Zulkarnain, Z.I. (2018) Autonomy, Workload, Work-Life Balance and Job Performance among Teachers. The International Journal of Educational Management, 32, 107-120.

https://doi.org/10.1108/IJEM-10-2016-0226 https://search.proquest.com/docview/1984723900?accountid=149218

[34] Oluremi, F. (2015) Attitude of Teachers to Students with Special Needs in Mainstreamed Public Secondary Schools in Southwestern Nigeria. The Need for a Change. https://goo.gl/5DQuAw

[35] Pellegrino, A. (2015) Pre-Service Teachers and Classroom Authority. American Secondary Education, 38, 62-78.

https://search.proquest.com/do.Mcview/722356586? accountid=149218

[36] Cheng, J. (2013) The Effect of Kindergarten Principals' Leadership Behaviors on Teacher Work Performance. Social Behavior and Personality, 41, 251-262. https://doi.org/10.2224/sbp.2013.41.2.251

[37] Ficarra, L. and Quinn, K. (2014) Teachers' Facility with Evidence-Based Classroom Management Practices: An Investigation of Teachers' Preparation Programmes and In-Service Conditions. Journal of Teacher Education for Sustainability, 16, 71-87. https://doi.org/10.2478/jtes-2014-0012

[38] Sachau, D.A. (2007) Resurrecting the Motivation-Hygiene Theory: Herzberg and the Positive Psychology Movement. Human Resource Development Review, 6, 377-393. https://journals.sagepub.com/doi/abs/10.1177/1534484307307546 https://doi.org/10.1177/1534484307307546

[39] Becker, T.E., Atinc, G., Breaugh, J.A., Carlson, K.D., Edwards, J.R. and Spector, P.E. (2016) Statistical Control in Correlational Studies: 10 Essential Recommendations for Organizational Researchers. Journal of Organizational Behavior, 37, 157-167. https://onlinelibrary.wiley.com/doi/full/10.1002/job.2053 https://doi.org/10.1002/job.2053

[40] Fouché, E., Rothmann, S. and van Corne, D.V. (2017) Antecedents and Outcomes of Meaningful Work among School Teachers. SA Journal of Industrial Psychology, 43, a1398. https://search.proquest.com/docview/1901423058? accountid=149218 https://doi.org/10.4102/sajip.v43i0.1398

[41] Yousaf, S.U., Usman, B. and Islam, T. (2018) Effects of Supervision Practices of Principals on Work Performance and Growth of Primary School Teachers. Bulletin 
of Education and Research, 40, 285-298.

https://search.proquest.com/docview/2103037651?accountid=149218

[42] Faremi, M.F. (2017) An Assessment of Teacher Retention and Job Security in Private Secondary Schools in Ogun State, Nigeria. Bulgarian Journal of Science and Education Policy, 11, 279-293.

https://search.proquest.com/docview/2076929600?accountid=149218 